\title{
STOPIEŃ OPANOWANIA SPRAWNOŚCI PISANIA U STUDENTA Z DYSFUNKCJĄ SŁUCHU - STUDIUM PRZYPADKU
}

Słowa kluczowe: surdoglottodydaktyka, glottodydaktyka, sprawność pisania, składnia

Streszczenie. Celem artykułu jest opis wybranych trudności, których doświadczał student z wadą słuchu w zakresie tworzenia tekstów w języku polskim. Materiał badawczy pochodzi z prac niedosłyszącego studenta Uniwersytetu im. Adama Mickiewicza w Poznaniu, który uczęszczał na fakultatywne zajęcia z praktycznej znajomości języka polskiego.

\section{SURDOGLOTTODYDAKTYKA}

Sytuacja osób z wadą słuchu w Polsce zmieniła się w ostatnim dziesięcioleciu, co wyraża się między innymi poprzez coraz większe zainteresowanie środowiska naukowego badaniami tej grupy z perspektywy lingwistycznej, psychologicznej, socjologiczno-kulturowej. Niewątpliwie jednym z ważniejszych punktów zwrotnych był fakt uchwalenia ustawy o języku migowym i innych formach komunikowania ${ }^{1}$. Ten dokument jest pierwszym, który gwarantuje osobom głuchym i głuchoniewidomym prawo do porozumiewania się za pomocą swobodnie wybranych metod (systemów) komunikacji niewerbalnej.

Wzrost zainteresowania językiem migowym sprawił, że na Wydziale Polonistyki Uniwersytetu Warszawskiego 1 czerwca 2010 r. powstała Pracownia Lingwistyki Migowej. Głównym celem jej działań jest stworzenie pełnego opisu gramatycznego i słownika polskiego języka migowego. W tym celu prowadzone są badania korpusowe wśród natywnych użytkowników tego języka.

*karuta@amu.edu.pl, Uniwersytet im. Adama Mickiewicza w Poznaniu, Wydział Filologii Polskiej i Klasycznej, Instytut Filologii Polskiej, Zakład Gramatyki Współczesnego Języka Polskiego i Onomastyki, ul. Fredry 10, 61-701 Poznań, ORCID: 0000-0003-1534-532X.

${ }^{1}$ Ustawa z dnia 19 sierpnia 2011 r. o języku migowym i innych środkach komunikowania się (Dz.U. z 2011 r. Nr 209, poz. 1243, z późn. zm.). 
Coraz częściej przedmiotem badań naukowych jest sposób komunikacji osób z wadą słuchu, znajomość języków obcych i stopnia opanowania poszczególnych sprawności językowych. Jeszcze do niedawna grupę badanych stanowiły dzieci lub młodzież ze szkół podstawowych, rzadziej licealnych. Co ważne z punktu widzenia wyników, badania te prowadzone były najczęściej przez osoby zajmujące się rehabilitacją mowy i reprezentujące medyczne podejście do głuchoty, gdzie brak słuchu oznaczał pewną niepełnosprawność, którą trzeba leczyć. Wraz ze wzrostem świadomości wśród słyszących zmieniała się perspektywa patrzenia na osoby niesłyszące, które dzisiaj uznawane są za członków mniejszości językowo-kulturowej, komunikujące się za pomocą języka opartego na modalności wizualno-przestrzennej. Dzisiaj brak kompetencji w polskim języku fonicznym nie jest traktowany już przez wielu badaczy jako przejaw dysfunkcji.

W dalszej części artykułu stosowane będą wymiennie pojęcia: osoba niedosłysząca i słabosłysząca. Określają one osoby, które posiadają wadę słuchu, ale odbierają mowę dźwiękową (wykorzystując resztki słuchu lub/i odczytują mowę z ust) i nie posługują się językiem migowym.

Opisywane w artykule zagadnienia sytuują się w obszarze badań surdoglottodydaktycznych, które stanowią połączenie surdopedagogiki z glottodydaktyką. Inicjatorką surdoglottodydaktyki jest Ewa Domagała-Zyśk, która użyła tego terminu po raz pierwszy w 2003 roku (Domagała-Zyśk 2003), a w 2013 roku opublikowała pierwsze w Polsce wyniki badań nad procesem nauczania i uczenia się języka obcego u studentów niesłyszących i słabosłyszących (Domagała-Zyśk 2013). Przedmiotem badań tej subdyscypliny „są zjawiska uczenia się i nauczania języka obcego osób z uszkodzeniami słuchu, a więc osób niesłyszących i słabosłyszących, a także zjawiska używania języków obcych przez te osoby (komunikowania się w języku obcym)" (Domagała-Zyśk 2013, s. 324).

W tym nurcie przyswajanie i nauka języka polskiego u osób niesłyszących i niedosłyszących również stanowi przedmiot zainteresowań. Gdy weźmie się pod uwagę sposób akwizycji języka ojczystego przez osoby z wadą słuchu, to można stwierdzić, że nie przebiega ona tak samo jak u słyszących Polaków. Dla niesłyszących i niedosłyszących niemożliwe jest przyswojenie języka polskiego w sposób naturalny, poprzez zanurzenie w nim (Lipińska 2006; Seretny, Lipińska 2012). Brak warunków fizycznych i nierzadko środowiskowych (brak wsparcia w rodzinie, brak kontaktu z językiem migowym) powoduje, że osoby z wadą słuchu nie przyswajają żadnego języka w stopniu umożliwiającym swobodną komunikację. Nierzadko są one bezjęzyczne, co oznacza, że nie opanowały żadnego języka w drodze naturalnej akwizycji. Fakt ten nie dziwi, gdy weźmie się pod uwagę, że ok. 90\% głuchych rodzi się rodzicom słyszącym. Funkcjonowanie głuchego dziecka w rodzinie jest utrudnione ze względu na brak środka komunikacji (rodzice nie znają języka migowego, dziecko nie słyszy języka fonicznego). Kontakt z językiem migowym jest często możliwy dopiero w chwili rozpoczęcia edukacji szkolnej w ośrodku szkolno-wychowawczym dla uczniów niesłyszących. 


\section{SPRAWNOŚĆ PISANIA}

Pisanie to sprawność, którą w języku ojczystym opanowuje się jako ostatnią. W przypadku osób z wadą słuchu kolejność ta jednak się zmienia. Pismo jest dla nich jednym z podstawowych kanałów komunikacji ze słyszącym otoczeniem; jest prymarną umiejętnością komunikacyjną. Istotny jest również fakt, że u niesłyszących nabywanie tej umiejętności odbywa się równolegle z przyswajaniem języka. Rozwój językowy w tym przypadku nie zakłada prymarności języka mówionego. Kazimierz Kowańdy zauważa, że w edukacji dzieci niedosłyszących sprawność pisania realizuje następujące cele:

1. wyrównuje skutki braku słuchu,

2. zwiększa szanse kontaktów z otoczeniem,

3. wzmacnia i przyspiesza rozwój umysłowy (Kowańdy 1998, s. 241).

Wśród uczniów z wadą słuchu istotne znaczenie ma stopień ubytku słuchu, który wpływa na rozwój sprawności językowych, w tym także na syntaktyczny poziom języka.

Badania nad sprawnością pisania wśród osób $\mathrm{z}$ wadą słuchu prowadzili między innymi Kazimierz Kowańdy (1998), Marta Korendo (Korendo 2007, 2008, 2012), Justyna Kowal (2005), Danuta Jastrzębska-Golonka i Agnieszka Rypel (2008). Wyniki analiz dowodzą, że niesłyszący uczniowie mają mniej trudności w rozumieniu mowy pisanej niż w posługiwaniu się nią w komunikacji. Sprawność czytania ze zrozumieniem u dzieci niedosłyszących jest 1,8 razy wyższa niż sprawność pisania (Kowańdy 1998, s. 249).

Wypowiedzi pisemne uczniów z deficytem słuchu cechują się konkretnością, stosowaniem kodu ograniczonego, niską spójnością semantyczną, ubogim słownictwem, nagromadzeniem błędów fleksyjnych, składniowych, stylistycznych, zachwianiem porządku przyczynowo-skutkowego, nagromadzeniem zdań pojedynczych, brakiem wykładników kohezyjnych i koherentnych (Jastrzębska-Golonka, Rypel 2008, s. 225; Korendo 2012, s. 195). M. Korendo uważa, że niski poziom sprawności pisania jest konsekwencją stosowania w pracy z uczniem z wadą słuchu złych metod nauczania. Zauważa ona, że nauczyciele popełniają błąd metodyczny, ponieważ dbają bardziej o to, by tekst był odpowiedniej długości niż o to, by uczeń stworzył spójną semantycznie wypowiedź pisemną:

Okazuje się jednak, że dużo lepiej byłoby, gdyby niesłyszący potrafili napisać trzy zdania, ale powiązane w pewną całość, z wykładnikami semantycznymi i gramatycznymi tej całości. Tymczasem uczniowie tworzą na siłę dziesięciozdaniową wypowiedź, ale frazy pozostają bez związku ze sobą, a nadawcy nie dbają o konstruowanie logicznej całości, ale o wyrobienie zadanej normy. Dlatego metody nauczania niesłyszących wymagają szybkiej weryfikacji na podstawie badań ich języka werbalnego i pisanego (Korendo 2012, s. 193). 
Warto podkreślić, że przywołane analizy dotyczą tekstów pisanych przez uczniów szkół podstawowych, gimnazjalnych i licealnych. W dostępnej literaturze przedmiotu niewiele uwagi do tej pory poświęcono starszym niesłyszącym. Dopiero prace Marcina Jury (2011) czy Ewy Domagały-Zyśk (2013) dotyczą studentów i osób dorosłych z wadą słuchu i ich trudności w nabywaniu języka ojczystego i angielskiego.

\section{ANALIZA MATERIALU BADAWCZEGO}

Materiał badawczy stanowią teksty pisane przez studenta $\mathrm{z}$ dysfunkcją słuchu, który uczęszczał na zajęcia fakultatywne z praktycznej znajomości języka polskiego. Był on słuchaczem dziennych studiów licencjackich na Wydziale Historycznym Uniwersytetu im. Adama Mickiewicza w Poznaniu. Nie zna polskiego języka migowego, jest głuchy od urodzenia, posiada głęboki niedosłuch obustronny. W jego rodzinie nie ma innych osób z wadą słuchu. Od 2. roku życia nosi aparaty słuchowe, a od 12. roku jednostronny implant ślimakowy. Ukończył liceum ogólnokształcące. Wszyscy studenci, którzy brali udział w zajęciach, posiadali różny stopień opanowania poszczególnych sprawności komunikacyjnych i językowych w zakresie języka polskiego, dlatego też w przypadku badań niesłyszących nierzadko trzeba traktować każdy przypadek indywidualnie. Różne doświadczenia językowe związane ze sposobem funkcjonowania w rodzinie, znajomością lub nie języka migowego, jak również inny stopień ubytku słuchu i czas jego powstania sprawia, że trudno jest znaleźć większą reprezentatywną grupe badanych.

Na materiał badawczy składają się dwa rodzaje tekstów. Pierwszym z nich jest praca licencjacka badanego, drugim są referaty zaliczeniowe, które musiał on napisać samodzielnie na zadany temat. Warto dodać, że student ten lubił czytać książki, szczególnie zainteresowany był historią średniowiecza.

Celem badania było skatalogowanie najczęściej występujących trudności $\mathrm{w}$ tworzeniu wypowiedzi pisemnych przez studenta $\mathrm{z}$ wadą słuchu. Może być to punkt wyjścia do dalszych, bardziej szczegółowych analiz (w tym także porównawczych), by na kolejnym etapie pomóc w stworzeniu odpowiednich programów pracy i materiałów dydaktycznych do nauki języka polskiego osób niesłyszących. W tekście nie pojawia się szczegółowa analiza występujących błędów ani ich geneza. Celem artykułu jest rozpoznanie ich i próba klasyfikacji. Dopiero w dalszej części badań sprawdzających poziom opanowania sprawności pisania dokonane zostanie ich bardziej precyzyjne omówienie, by móc postawić hipotezy na temat miejsc trudnych w polszczyźnie u osób z dysfunkcją słuchu. 
W badanych tekstach studenta dominują trudności na poziomie ukształtowania składniowego wypowiedzi. Wśród nich wymienić można naruszenie związku zgody podmiotu z orzeczeniem:

a) Układ organizacji zakonu była trzystopniowa ${ }^{2}[\ldots]$

b) Lecz w klasztorze wciąż byla żywy kult Jackowy [...]

c) Narodziny Jacka jest trudne do ustalenia [...]

d) Jest też konie i port rybacki.

e) [...] stwierdził, że odmowa papieża pokrzyżowały jego plany i projekt reformy rozbiły się z konserwatyzmem soboru oraz kurii.

f) Cała zmiana wynikało nie $z$ nieuwagi notariusza [...]

g) Zapadła gorąca noc, koncertuję świerszcze i komary.

W powyższych przykładach niewłaściwe formy fleksyjne powodują zaburzenie związku składniowego między podmiotem i orzeczeniem. W dwóch pierwszych $(\mathrm{a}, \mathrm{b}) \mathrm{w}$ funkcji podmiotu występuje rzeczownik rodzaju męskiego (uktad, $k u l t$ ), zaś łącznikowi w orzeczeniu słowno-imiennym błędnie przypisano rodzaj żeński (była). W pierwszym zdaniu również orzecznik posiada formę rodzaju żeńskiego (trzystopniowa). Co ciekawe, w drugim przykładzie forma orzecznika jest poprawna. Być może wynika to ze struktury zdania, w której orzecznik występuje przy podmiocie. Student mógł dopasować jego rodzaj do postaci gramatycznej podmiotu. W dwóch kolejnych przykładach $(\mathrm{c}, \mathrm{d})$ również występują błędy wynikające z nieprawidłowej liczby łącznika w orzeczeniach złożonych, co powoduje naruszenie związku zgody między podmiotem a orzeczeniem (narodziny jest trudne, jest konie i port). Niezgodność gramatyczna podmiotu i orzeczenia pojawia się również w zdaniach ostatnich (e, f, g) (zmiana wynikato, odmowa pokrzyżowały, koncertuję świerszcze i komary).

Nierzadko występują również niewłaściwe wskaźniki zespolenia:

a) Ta idea jednak powstała znacznie wcześniej - podczas wyprawy z biskupem Diego, gdzie zatrzymali się w Francji i było pełno heretyków.

b) Cieszę się, że tam mogłam występować ale mam nadzieję że w przyszłym roku tam pojadę i będzie sukces.

c) Po powrocie z Rzymu dokonali wyboru, więc zdecydowało się opierać się reguły św. Augustyna, oraz sporządzili ustawy uzupełniając w całości dla zakonu.

d) Powstanie tego nowego zgromadzenia jest całkowicie nowość gdyż, dlatego zlecono im głoszenia Słowa Bożego, którego obowiązkiem mieli tylko biskupi.

e) Też podobnie nie rozumieli postawy bracia, gdyż dlatego wyruszali w inne miejsce, gdzie ich nie znano obawiano się również także o problemy o noclegi czy środki utrzymania.

W powyższych przykładach uwidacznia się przede wszystkim niedostateczna kompetencja w zakresie tworzenia wypowiedzeń współrzędnie i podrzędnie złożonych. Brak znajomości znaczenia spójników powoduje ich błędne użycie. We

${ }^{2}$ Analizowane wypowiedzi podawane są w wersji oryginalnej. Pogrubienia w cytatach pochodzą od autorki tekstu. 
wszystkich przykładach niepoprawny wybór wskaźnika zespolenia sprawia, że trudne staje się odnalezienie związków logicznych między poszczególnymi zdaniami składowymi wypowiedzenia złożonego. W pierwszym przykładzie spójnik „gdzie” wprowadza błędne zdanie podrzędnie złożone okolicznikowe miejsca. Być może wskaźnik ,gdzie” odnosić się miał do drugiej części wypowiedzenia (byto petno heretyków). Poprawnie zbudowane zdanie brzmi:

Ta idea jednak powstała znacznie wcześniej - podczas wyprawy z biskupem Diego, podczas której zatrzymali się we Francji, gdzie było pełno heretyków.

W porównaniu z badaniami tekstów pisanych przez młodszych uczniów (Korendo 2007, 2008, 2012), zauważyć trzeba, że w pracach studenta znacznie częściej występują zdania złożone. Student przykłada wagę do sposobu prowadzenia narracji, podejmuje starania o bardziej rozbudowany styl wypowiedzi. Trudność w tworzeniu zdań złożonych polega na nieznajomości syntaktycznych wykładników hipotaksy i parataksy. Błędne użycie syntaktycznych wykładników współrzędności i podrzędności powoduje zaburzenie spójności gramatyczno-formalnej. W powyższych przykładach niewłaściwe wskaźniki zespolenia utrudniają odczytanie związków przyczynowo-skutkowych przez brak powiązań składniowych pomiędzy poszczególnymi zdaniami składowymi wypowiedzenia złożonego. Nie świadczy to jednoznacznie o tym, że są to zagadnienia, których student nie może opanować ze względu na poziom ich trudności. Być może błędy wynikają z faktu, że na wcześniejszych etapach edukacji zagadnienia te nie zostały wprowadzone w sposób umożliwiający ich zrozumienie i/lub nie przeprowadzono odpowiedniej liczby ćwiczeń pozwalających na przełożenie teorii na praktykę.

W materiale badawczym pojawiają się również błędy w wyrażaniu stosunków przestrzennych / czasowych poprzez niepoprawne użycie przyimków:

a) Kościelny Matteo postanowił wejść do podziemi kościoła i niestety podczas podnoszenia sarkofagu ześlizgnął się i zranil na nogę.

b) Rok 1764 odbyła się wolna elekcja, która miała wybrać nowego władcy po śmierci Augusta III Sasa, został wybrany na tron polski Stanisław Antoni Poniatowski

c) Uchwalenie Ustawy Rządowej miało odbyć się w 5 maja

d) wojska rosyjskie wkroczyły na ziemiach Rzeczypospolitej w 18 maja

e) Rozpoczęcie konfederacji targowickiej rozpoczęło się nie w 14 maja w Targowicy, która jeszcze leżało po polskiej stronie, lecz wcześniej w dniu 17 kwietnia 1792 roku w Petersburgu.

f) Przyczyną powstania zakonu dominikańskiego najpierw trzeba zrozumieć, jakie doszły okoliczności i sytuację Kościoła w pod koniec XII i początku XIII wieku.

W przykładzie a) przyimek „na” został użyty błędnie. Przyimek ten w języku polskim występuje między innymi tam, gdzie mówi się o miejscu dziania się jakiejś czynności (USJP 2003, s. 757), np. Zmierzamy na pótnoc, Śpia na podłodze. Kłopoty z poprawnym użyciem tego przyimka mogą wiązać się z fak- 
tem, że ma on taką samą rekcję jak przyimek „w”3. Różnica polega na tym, że przyimek „na” znajduje swoje zastosowanie przy określaniu większych przestrzeni, obiektów, dlatego poprawne są zdania typu Zmierzamy na pótnoc czy Śpia na podłodze. Przyimek „w”, który powinien się pojawić w analizowanym przykładzie a) oraz b), pełni funkcję lokalizatora punktowego i wskazuje konkretne miejsce w przestrzeni: Zranit się $w$ nogę. W kolejnych przykładach (c, d, e) można zaobserwować zjawisko hipertrofii przyimka „w”, którego pojawienie się przy wskazywaniu daty jest zbędne. Użycie go wynikać może z analogii z określeniami czasu odnoszącymi się do pór dnia, miesiąca, roku (np. w zeszlym tygodniu, $w$ poludnie, $w$ grudniu). Niepotrzebny przyimek pojawił się również $\mathrm{w}$ ostatnim przykładzie (f). Doszło tu do kontaminacji dwóch schematów: $w$.... wieku oraz pod koniec .... wieku.

W analizowanych tekstach poza uchybieniami na poziomie związków zdaniowych cechują się zaburzeniami na poziomie delimitacji składniowej:

a) Ale niestety ze względu uchwały kanonu soborowe, które zabraniały zakładania nowych wspólnot zakonnych.

b) Która była bardzo ważne podczas tworzenie nowego klasztoru zakazano istnienia bez lektorów, gdyż od początku dbano współbraci przygotowanie intelektualnie.

c) Kiedy podczas wyprawy przez południową Francję, gdzie zatrzymali się w gospodzie, jak okazało się, że właściciela należał do sekty katarów. Więc Dominik podjął z tym człowiekiem całonocnej rozmowie, dyskutowano na temat Biblii, czy teologii i z tym zakończyło się sukcesem - ów heretyk powrócił do wiary katolickiej.

d) Kiedy otrzymał bullę z dnia 4 listopada 1219 r. o tym, że zostanie arcybiskupem.

e) Po chwili poszliśmy po śniadanie i zjedliśmy było bardzo smaczne.

W powyższych przykładach uwidaczniają się trudności w tworzeniu wypowiedzeń jako samodzielnych jednostek składniowych. Przykład b) jest niepełny semantycznie, o czym świadczy zaimek przymiotny względny na początku wypowiedzenia, który funkcjonuje jako wskaźnik zespolenia w zdaniu podrzędnie złożonym przydawkowym. W przykładzie tym brakuje zdania nadrzędnego. $\mathrm{Z}$ taką samą sytuacją mamy do czynienia w przykładzie d). Zdanie e) to zestawione ze sobą dwa wypowiedzenia: Po chwili poszliśmy po śniadanie i zjedliśmy (je) ${ }^{4}$ oraz Było bardzo smaczne. Pomijanie znaków interpunkcyjnych zaburza logiczny tok wywodu.

Niepoprawne wydzielanie samodzielnych jednostek składniowych prowadzi często do zaburzenia porządku przyczynowo-skutkowego, co widoczne jest w poniższych przykładach:

a) Pierwszy dokument papieski z 1216 r., o którym wspomniałem wcześniej, stała symboliczną datą powstania zakonu, gdyż wystawiono w bazylice św. Piotra w Watykanie, gdzie podpisano obok papieża 18 kardynałów.

${ }^{3}$ Szczegółowa analiza przyimków przestrzennych w tekstach pisanych w języku polskim przez osoby niesłyszące znajduje się w artykule K. Ruty i M. Wrześniewskiej-Pietrzak (2017).

${ }^{4} \mathrm{~W}$ nawias wprowadzono zaimek, by zdanie było poprawne. 
b) Zakon kaznodziejski założony przez św. Dominika Guzmána odegrała bardzo ważną rolę w Kościele katolickim. Całkiem nowego dla tej wspólnoty, która otrzymała od papieża przywilej głoszenia kazania, gdyż kaznodzieją ex officio posiadał biskup.

c) Wstęp tej książki ukazuje św. Jackowi doskonałości i oświecał Polaków światłością wiary.

W przykładach tych występują konstrukcje, które mają naruszoną strukturę syntaktyczną i niekiedy również semantyczną. Jednak najczęściej te zakłócenia formalne nie zaburzają całkowicie sensu wypowiedzi i uważny czytelnik jest w stanie odczytać intencję autora. Jolanta Panasiuk i Tomasz Woźniak (2001) teksty o zaburzonej formie graficznej, ortograficznej, w których naruszona zostaje spójność formalna i semantyczna nazywają patologicznymi (Panasiuk, Woźniak 2001, s. 123). Anna Dąbrowska, analizując błędy w pracach pisemnych cudzoziemców, wyróżniła składniową konstrukcję dysmorficzną. Wypowiedzenia tego rodzaju definiowane są jako ,sekwencja słów pełna usterek morfologicznych, składniowych, semantycznych, czasem logicznych, w której trzeba w procesie odbioru wydobyć poszczególne informacje i złożyć je na nowo" (Dąbrowska 2012, s. 84). Występują one często w analizowanym materiale:

Ale ze względu okoliczności, jakie pojawiły się nowych sekt heretyckich, więc papież zdecydował nadać braciom zakonu kaznodziejskiego głosić Słowo Boże i od początku dominikanie byli gruntownie nastawieni na oparcie działalności braci o dobrze przygotowanie intelektualne stworzył bardzo szybko cały system szkolny, który stał się w następnych latach stając się wzorem dla innych takich systemu tworzącego się przez pozostałych zakonów żebrzących.

W powyższym przykładzie został naruszony schemat składniowy poprzez niepoprawne użycie spójnika „więc”, wystąpiły błędne końcówki fleksyjne (takich systemu zamiast takich systemów; pozostałych zakonów żebrzacych zamiast pozostate zakony żebrzace), użycia przyimków i zaimków lub ich brak (ze względu okoliczności - brak przyimka „na”; pojawity się nowych - brak przyimka „w”; systemu tworzacego się przez - zbędny zaimek „,się”). Wystąpiły także składniki redundantne (stając się), które dodatkowo wprowadziły relację hipotaktyczną oraz błędne części mowy (dobrze zamiast dobre). Ponadto zdanie to jest zbyt długie. Dokonać można jego korekty możliwie najmniej ingerującej w strukturę zdania:

Ale ze względu na okoliczności, jakie pojawiły się w nowych sektach heretyckich, papież zdecydował, by bracia zakonu kaznodziejskiego głosili Słowo Boże. Od początku dominikanie zwracali uwagę na dobre przygotowanie intelektualne i szybko udało im się stworzyć system szkolny, który w późniejszych latach stał się wzorem dla innych takich systemów tworzonych przez zakony żebrzące.

Wypowiedzenie może być uznane za składniową konstrukcję dysmorficzną, gdy cechuje się m.in. zaburzeniami semantycznymi i formalnymi, niepoprawną formą gramatyczną składników, niepoprawną rekcją, brakiem zgody między składnikami, niepoprawnym lub nieneutralnym szykiem składników, niepopraw- 
nym użyciem leksemów lub naruszeniem zasad łączliwości semantycznej, niespójnością stylistyczną (Dąbrowska 2012, s. 86). Nie muszą wystąpić wszystkie wymienione wyżej elementy w jednym wypowiedzeniu. Poprawa takich zdań wymaga głównie zmian w zakresie składni:

Przyczyną powstania zakonu dominikańskiego najpierw trzeba zrozumieć, jakie doszły okoliczności i sytuację Kościoła w pod koniec XII i początku XIII wieku. (Korekta: By zrozumieć przyczyny powstania zakonu dominikańskiego najpierw trzeba zrozumieć, w jakich okolicznościach miało to miejsce i jaka była sytuacja Kościoła pod koniec XII i na początku XIII wieku.)

Wydarzenia, jakie wydarzyło się w gospodzie, jak również chęć podjęcia działalności misyjne podczas drugiej wyprawy do Dani w 1205 r., że im wyrwało mocne wrażenie, że w drodze powrotnej, zatrzymali się w Rzymie. (Korekta: Wydarzenia w gospodzie oraz chęć podjęcia działalności misyjnej podczas drugiej wyprawy do Danii w 1205 roku sprawiły, że w drodze powrotnej zatrzymali się w Rzymie.)

Po powrocie z Rzymu dokonali wyboru, więc zdecydowało się opierać się reguły św. Augustyna, oraz sporządzili ustawy uzupełniając w całości dla zakonu. (Korekta: Po powrocie z Rzymu zdecydowali opierać się o reguły św. Augustyna i sporządzili ustawy uzupełniające dla całego zakonu.)

Informacja o samym autorze jest niewiele informacji i wiadomo, że było pełnił obowiązki lektora w klasztorze w Krakowie przed 1352 roku. (Korekta: Informacji o samym autorze jest niewiele. Wiadomo jedynie, że pełnił obowiązki lektora w klasztorze w Krakowie przed 1352 rokiem.)

Podczas obrady soborowe wiemy, że także brali w nim biskup Fułko wraz Dominikiem, którzy starali się na zgodę od papieża na utworzenia nowego zakonu.(Korekta: Wiemy, że w obradach soborowych brali udział biskup Fułko i Dominik, którzy starali się o zgodę od papieża na utworzenie nowego zakonu.)

Dokonano wolnej elekcji, cóż niestety wypadło gorzej: cześć kapituły oddała głosy na swego dziekana - Hugona, a pozostali na proboszcza krakowskiego - Boguchwała. (Korekta: Dokonano wolnej elekcji: część kapituły oddała głosy na swojego dziekana - Hugona, a pozostali na proboszcza krakowskiego - Boguchwała.)

W powyższych przykładach poza wadliwą strukturą zdania złożonego uwidacznia się niedostateczne opanowanie systemu gramatycznego i leksykalnego polszczyzny. Świadczą o tym liczne błędy leksykalne związane ze złą formą utartych fraz wyrazowych (doszły okoliczności - popr. zaszły okoliczności, wyrwało wrażenie - popr. wywarło wrażenie, starali się na zgodę - popr. starali się o zgodę), powtórzenia wyrazowe (wydarzenia, jakie wydarzyło się; informacja o samym autorze jest niewiele informacji), jak również błędy użycia ${ }^{5}$, wśród których pojawiają się błędy związane z rekcją przyimka i czasownika.

\footnotetext{
${ }^{5}$ Klasyfikacja błędów zaczerpnięta została z pracy A. Dąbrowskiej i M. Pasieki (2008).
} 


\section{PODSUMOWANIE}

Pisanie tekstów jest dla niesłyszących jednym z najczęstszych środków komunikacji z otoczeniem. Opisane trudności w zakresie tworzenia wypowiedzi pisemnych dowodzą, że mimo wieloletniej edukacji szkolnej opartej na języku polskim nie jest to sprawność opanowana w stopniu zadowalającym. Nietrudno wskazać błędy składniowe, które obrazują brak wystarczających kompetencji językowych w pisaniu tekstów spójnych, poprawnych gramatycznie, z zachowaniem porządku logicznego. Biorąc pod uwagę typologię błędów w perspektywie glottodydaktycznej (Dąbrowska, Pasieka 2008), stwierdzić należy, że w pracach studenta pojawiają się głównie błędy użycia, a nie formy. W związku z tym - jak zauważa E. Domgała-Zyśk - przy ocenie wypowiedzi pisemnych osób nie(do)słyszących trzeba zwracać uwagę nie tylko na liczbę błędów językowych, które są oznakami niepełnosprawnościami słuchu, ale także (a może przede wszystkim) na realizację celu wypowiedzi (E. Domagała-Zyśk 2003). Trudności w pisaniu, jakie zostały zaprezentowane w tekście, świadczą o niedostatecznym opanowaniu systemu gramatycznego polszczyzny.

Jak wynika z przedstawionej powyżej analizy studium przypadku studenta z wadą słuchu, trudności, jakie pojawiały się w jego wypowiedziach pisemnych, są podobne do tych, które popełniają cudzoziemcy uczący się języka polskiego na lektoratach ${ }^{6}$. Dlatego też w pracy z osobą niedosłyszącą słuszne wydaje się korzystanie z metod i pomocy dydaktycznych wypracowanych na gruncie glottodydaktyki. Przy czym trzeba mieć świadomość istnienia różnic pomiędzy niesłyszącymi, które mają różne podłoże (model wychowania w rodzinie, doświadczenie językowe, wcześniejsza edukacja, ale też rodzaj głuchoty, stopień utraty słuchu, wiek, w którym doszło do zaburzenia itp.). Z tych względów nierzadko proces uczenia wymaga indywidualnego podejścia. Stopień opanowania sprawności pisania wynikać może z ogólnych trudności w posługiwaniu się językiem polskim i nie odzwierciedla w pełni kompetencji studenta. Dopiero zrozumienie specyfiki tych trudności pozwala na opracowanie programu kształcenia językowego, który będzie dostosowany do potrzeb i możliwości osoby z wadą słuchu. Biorąc pod uwagę fakt, że coraz więcej niesłyszących podejmuje studia, to jest to zadanie konieczne, by umożliwić tym osobom swobodną komunikację i zdobywanie wiedzy w ich języku narodowym.

${ }^{6}$ Wniosek ten wysuwają wszyscy badacze zajmujący się polszczyzną głuchych. Por.: Januszewicz 2011; Jura 2011; Kowal 2011. 


\section{BIBLIOGRAFIA}

Dąbrowska A., 2012, Składniowa konstrukcja dysmorficzna jako błąd kompleksowy, „Poradnik Językowy", nr 6, s. 82-93.

Dąbrowska A., Pasieka M., 2008, Błędy językowe w tekstach pisanych przez cudzoziemców - wybrane problemy zwiazane z klasyfikacją i ocena, w: A. Seretny, E. Lipińska (red.), Rozwijanie i testowanie biegłości w języku polskim jako obcym, Kraków, s. 103-113.

Domagała-Zyśk E., 2003, Czy istnieje już polska surdoglottodydaktyka, „Języki Obce w Szkole”, nr 4, s. 3-7.

Domagała-Zyśk E., 2013, Wielojęzyczni. Studenci niestyszacy i słabostyszacy w procesie uczenia się i nauczania języka obcego, Lublin.

Januszewicz M., 2011, Lektoraty języka polskiego jako obcego dla Gtuchych w Szkole Języka Polskiego i Kultury dla Cudzoziemców Uniwersytetu Wrocławskiego. Trudności, osiagnięcia, perspektywy, w: K. Pluskota, K. Taczyńska (red.), Nowe perspektywy w nauczaniu języka polskiego jako obcego II, Toruń, s. 29-36.

Jastrzębska-Golonka D., Rypel A., 2008, Specyfika tworzenia tekstów przez uczniów z deficytami stuchu - wybrane zagadnienia, w: J. Porayski-Pomsta (red.), Mowa i język w perspektywie dydaktycznej, logopedycznej i rozwojowej, Warszawa, s. 222-235.

Jura M., 2011, Polszczyzna Gluchych, w: K. Pluskota, K. Taczyńska (red.), Nowe perspektywy wnauczaniu języka polskiego jako obcego II, Toruń, s. 37-50.

Korendo M., 2007, Przykłady tekstów pisanych, czyli jak teoria językoznawcza przystaje do rzeczywistości niestyszacych, w: A. Maciejewska (red.), Zaburzenia komunikacji językowej w czytaniu i pisaniu, Siedlce, s. 87-97.

Korendo M., 2008, Jak niestyszący gimnazjaliści radza sobie z opisem obrazka? Analiza przykładów, w: J. Porayski-Pomsta (red.), Mowa i język w perspektywie dydaktycznej, logopedycznej i rozwojowej, Warszawa, s. 213-221.

Korendo M., 2012, Jak niestyszacy piszą o sobie? Analiza przykładów, w: K. Krakowiak, A. Dziurda-Multan (red.), Wychowanie dzieci z uszkodzeniami stuchu - nowe wyzwania dla rodziców i specjalistów, Lublin 2012, s. 187-197.

Kowal J., 2005, Trudności w czytaniu i pisaniu dzieci niedostyszących i głuchych, „Nauczyciel i Szkoła", nr 1-2, s. 104-120.

Kowal J., 2011, Język polski jako obcy w nauczaniu milczących cudzoziemców, rozprawa doktorska, Uniwersytet Wrocławski [maszynopis].

Kowańdy K., 1998, Zaburzenia językowe w mowie pisanej dzieci niedostyszacych, w: U. Eckert (red.), Wybrane zagadnienia z surdopedagogiki, Warszawa, s. 240-267.

Lipińska E., 2006, Przyswajanie języka pierwszego a uczenie się języka obcego / drugiego, w: E. Lipińska, A. Seretny (red.), Z zagadnień dydaktyki języka polskiego jako obcego, Kraków, s. 19-28.

Panasiuk J., Woźniak T., 2001, Pojęcie tekstu a zaburzenia mowy, w: S. Grabias (red.), Zaburzenia mowy, Lublin, s. 108-132.

Ruta K., Wrześniewska-Pietrzak M., 2017, Przyimki przestrzenne w tekstach pisanych $w$ języku polskim przez osoby niestyszace - uwagi wstępne, „Polonica”, t. XXXVII, s. 137-148.

Seretny A., Lipińska E., 2012, Między językiem ojczystym a obcym. Nauczanie i uczenie się języka odziedziczonego na przyktadzie szkolnictwa polonijnego w Chicago, Kraków. 
Karolina Ruta-Korytowska

\section{HEARING-IMPAIRED STUDENT'S DIFFICULTY WITH WRITING SKILLS - A CASE STUDY}

Keywords: glottodidactics, writing skill, syntax

Summary. The aim of the article is to describe selected difficulties with writing in Polish experienced by a hearing-impaired student. The research material comes from a B.A thesis and selected other texts written by a student of Adam Mickiewicz University in Poznań, who attended optional classes in practical knowledge of the Polish language. 